\title{
Tawuran Pelajar: Solidarity in the Student Group and its Influence on Brawl Behaviour
}

\author{
Elly Malihah $^{1 \bowtie}$, Bunyamin Maftuh ${ }^{1}$, Rizki Amalia ${ }^{1}$ \\ ${ }^{1}$ Sociology Education Programme, FPIPS UPI, Bandung
}

Permalink/DOI: http://dx.doi.org/10.15294/komunitas.v6i2.3301

Received : July 2014; Accepted: August 2014; Published: September 2014

\begin{abstract}
This research is motivated by the reality of the student brawls as a result of increasing solidarity within the students group. This problem emerges as a challenging issue for our education. This study aims to find an answer to the question of how solidarity within student groups in influencing the brawl behavior. The study used a qualitative approach and case study method. Data was collected through interviews, observation, documentary studies, and literature. The findings of the study are: (1) the brawl between students is triggered by hostility, disputes, or conflicts among student groups. (2) The recruitment process of a student groups is natural and based on the proximity of their house location or place of residence, mutual interests, as well as their hang out place. (3) The process of solidarity formation among group members begins with the casual interaction, carrying out activities together, and establishing the feeling of unity. (4) This established group solidarity leads the students to conduct the brawls when their group is under the threat from the other groups. The students will also do the brawls when there are conflicts among students groups and they fail to fulfill their developmental needs as a teenager.
\end{abstract}

\begin{abstract}
Abstrak
Penelitian ini dilatarbelakangi oleh realitas maraknya tawuran dikalangan pelajar sebagai dampak dari meningkatnya solidaritas dalam kelompok. Masalah tersebut menjadi tantangan dunia pendidikan. Penelitian ini ingin memperoleh jawaban atas pertanyaan bagaimana solidaritas pada kelompok pelajar dalam mempengaruhi perilaku tawuran. Penelitian ini menggunakan pendekatan kualitatif dan metode studi kasus. Teknik pengumpulan data dilakukan melalui wawancara, observasi, studi dokumentasi, dan studi literatur. Temuan penelitian: (1) Tawuran antar pelajaryang terjadi dikarenakan permusuhan, pertikaian atau konflik yang ada diantara kelompok-kelompok pelajar. (2) Proses pelajar menjadi anggota kelompok bersifat alamiah dan didasari karena kedekatan letak rumah atau tempat tinggal, minat yang sama, serta satu tempat tongkrongan. (3) Proses pembentukan solidaritas dimulai dari interaksi diantara sesama anggota kelompok, kegiatan yang dilakukan bersama-sama hingga akhirnya keterlibatan perasaan. (4) Solidaritas yang terbentuk menyebabkan tawuran antar pelajar selama ada ancaman dari kelompok lain, terjadinya konflik diantara kelompok-kelompok pelajar, serta tidak terpenuhinya kebutuhan-kebutuhan perkembangan pelajar sebagai remaja.
\end{abstract}

Keywords: group; group solidarity; and brawl

How to Cite: Malihah, E., Maftuh, B., \& Amalia, R. 2015. Tawuran Pelajar: Solidarity in the Student Group and its Influence on Brawl Behaviour. Jurnal Komunitas, 6(2):212-221. doi:http://dx.doi.org/10.15294/komunitas. v6i2.3301

(C) 2014 Semarang State University. All rights reserved

Corresponding author:

Address: Setiabudi Street, No. 229 Bandung

E-mail: lestarisam@yahoo.co.id

ISSN 2086-5465

UNNDS JOURNALS




\section{INTRODUCTION}

Schools should comprehensively develop their students' potentials including their spiritual, social, intellectual and emotional intelligences as well as their skills as regulated in the Act No. 20 of 2003 on the National Education System. However, after such a long time implementing the curriculum of 1945 until KTSP 2006 (School Based Curriculum), the Indonesian schooling system has been solely focusing on the development of cognitive aspects. The condition is proven by the strong pressure from the central government to implement the system of national examination which only advocates the cognitive intelligence tests alone used as a determining factor of students' graduation.

Lack of attention on the other aspects besides makes the education in Indonesia experiencing a tangible moral decadence. Currently, students become more uncontrolled, grouping-oriented, and violent in carrying out their activities. In resolving their problem, students tend to do violence, fighting, and brawl.

Indonesian Commission for Child Protection (KPAI) reveals that during 2012 they recorded 339 cases of student brawls which resulted in 82 students' deaths. The number had increased dramatically. In 2010 , the recorded student brawl cases were only 128 cases. This condition gains some concerns from various parties. Maftuh (2008: 9) states that "whatever the form is, if a conflict exists, the conflict will at least disrupt the learning process and then will weaken the learning process and achievement". Therefore, if the student brawls cannot be stopped, the next generation will emerged in a violent culture and will no longer think of achievement that can advance the nation.

The main actors on students brawl are the teenagers themselves. Usually, young people have a high sense of solidarity, especially a sense of solidarity within their group. This solidarity arises because of the feeling of kinship among their group. They also experience similar disappointment feeling or offense on their dignity done by the other groups. Therefore, they create bond with each other to get together in a group. Durkheim (Johnson, 1986: 181) states that: "a sense of solidarity that emerges in a group occurs because students share mutual moral and beliefs which are strengthened by their similar emotional experiences".

However, in the case student brawls, students' solidarity held in each group turns into a negative aspect. The students brawl can cause disintegration between groups and result in the changes of students' behavioral patterns to be more violent and courageous in doing beating, clash, persecution, and destruction which usually cause casualties. Although there are many factors which influence a students' brawl, the sense of solidarity within a group becomes the dominant factor.

Based on the observations made by the researcher in the past few years, student brawls that occurred in Sukabumi are increasingly prevalent and have an increasing victim's injuries or fatalities as compared to the other regions. Students brawl is like a virus which spreads from one region to another. In Sukabumi, the brawls between students initially occur in the area of Jampang and Pelabuhan Ratu, southern region of Sukabumi. However, from time to time, the brawls continue to spread to the northern region of Sukabumi Regency.

The fact is not fully revealed because Sukabumi is not a big city like Jakarta and other big cities. Therefore, some brawls that resulted in deaths are less of a concern of the central government and society. In addition, not too much news is reported. Besides, if a brawl incident which leads to casualties and deaths happens in Jakarta and the other major cities, it will get massive attention from the public, central government, and all media; both print and electronic media.

On the preliminary study conducted by researcher during the past five months, some of the factors that lead the students to fights or do the brawls in Sukabumi are differences of school attributes which identify of the school, act of teasing on each other, personal grudges, revenge action done by students groups, scrambling the public transportations to their place of hang out, and 
revenge which is derived from their previous generations toward other schools which can trigger a conflict over a small problem.

This existing factors and reality encourages the researcher to assess and conduct a thorough and in-depth research on students' solidarity groups in affecting their brawl behavior that occur in Sukabumi. This study concerns on some factors which make the students willing to do the fight and sacrifice their safety or even their lives.

\section{METHODS}

This study used a qualitative approach. The first reason of using qualitative approach is because this study aims to understand the solidarity that is formed in the group. Secondly, a qualitative approach was used to understand the social phenomenon of the brawl between students which happened frequently these days through a thorough overview and in-depth understanding. Therefore, the brawl is not only viewed as a social phenomenon caused by the juvenile delinquency but also viewed from the standpoint of ethics.

Another reason of why the researcher used a qualitative approach for research on group solidarity in affecting the brawl behavior was because this research required an in-depth analysis. This study did not rely on the research results. The process of research played significant role in this study. Besides, a human behavior could not only be measured by statistical calculations and every human behavior had meaning and factors that lied behind them. Therefore, those reasons reinforced the researcher to use a qualitative approach to examine the effect of group solidarity in students' brawl behavior in Sukabumi.

The method used in this study was a case study. Case study is a method which examines a case and obtains a detailed picture of the case. Cases raised in this study were related to the brawls between students that occur in Sukabumi. Therefore, this research on the brawl behavior of group solidarity used case study because although student brawls occurred in some areas but brawl cases that occurred in Sukabumi had unique characteristics. In addition, researcher wanted to get a detailed picture regarding to students brawl that has been continuing until today.

Data collection technique used in this research was through interviews, observation, literature review, and documentation. The data analysis techniques were conducted through three stages, namely data reduction, data display, and final conclusion. In the data reduction stage, the researcher carefully selected the needed data and then made a qualitative table to make it more easily to understand. The validity of test data was conducted by researchers through triangulation, member check, and analysis of negative cases.

\section{RESULTS}

The students brawl is actually caused by the existence of inappropriate solidarity which leads to the negative effects on the togetherness within the groups. The existence of group solidarity is very helpful but when solidarity is placed in a wrong place, this solidarity becomes dangerous. Students brawl started to appear from 2007 in the area of Jampang or included in Pajampangan zone.

However, there was already hostility between groups of different schools before. They claimed that this rivalry between schools has existed since long time ago. The current schools even do not know exactly what caused the hostility at first until now. As the time goes by, the students' brawls continue to spread to the other areas covering Pelabuhan Ratu and North zones and it reached the peak in 2009-2011.

For one semester, the students of vocational high school (SMK) Dwi Darma only involved in one brawl which happened on Monday the 2nd of September 2013. They called the brawl as an unfortunate incident. The brawl resulted in casualties from other schools due to the stabbing conducted by two students from SMK Dwi Dharma Therefore they had to be punished for three years. Another student brawl occurred on Monday 2 September 2013 in the northern part Cicurug Sukabumi between students from SMK Dwi Darma with students from SMK 
Lodaya. The brawl happened in the late afternoon at 16:00 pm, resulting two students from SMK Lodaya got serious injuries. There are multiple stabs on the victims' bodies on their head, shoulders and their backs. Fortunately, the victims were not dead. Students who did the stabbing were two students from SMK Dwi Darma. The two were then sentenced to three years imprisonment in Nyomplong Prison, Sukabumi.

Over the past one year, in the police area of Cibadak, there were two student brawls which were investigated by the police; the brawls happening on 9th and 16th November 2013. During that time, when there was mass gathering or group of students, they would be directly dissolved and students were immediately sent home. That was because the society played an active role in reporting such gathering to the police. So if there were many students suspiciously gathering, they would be immediately dissolved by the public or the police.

The brawl occurred on Saturday, 9 November 2013 was immediately investigated and handled by police of Cibadak. However, the SMK Lodaya attacking case which happened on 16 November 2013 was directly handled by the Police of Sukabumi because both cases were counter reports. The results of anatomy crime for cases of November 9 2013 resulted in three suspects consisted of two underage suspects and one adult person.

Based on the observations and interviews from several informants, the internal or driving factors to be a member of particular group are: (1) the need for self-actualization, (2) the need to be recognized in their environment or friends groups, (3) the need for affection, (4) the comfortable feeling within the group, (5) the feeling of being protected, (6) the need to fulfill their basic material needs (to borrow money, clothes, etc.), (7) the need to get help, (8) the need to get partners to hang out.

In addition to the mentioned driving factors of the students to join a group, there are also some external factors that makes students want to be part of that group, namely: (1) possessing the same vision and mission, (2) envisioning the same goals, (3) having the same interests, (4) having the same character, (5) being able to fulfill a sense of comfort, (6) being able to meet the need to be recognized, (7) being able to meet the needs of self-actualization, (8) being able to meet the material needs, (9) being able to meet the satisfaction of students, (10) the insistence of the group.

The above factors are the factors which cause the student eventually join the group. Most importantly, the geographical location of the house is the main determinant factor of a student to be a member of a particular group. Furthermore, these groups form a group on the basis of their home routes. It is further clarified by the evidence that the brawls happened several times because of this reason.

In addition, the group is not influenced by the similarity of age or grade. These groups have different classes and levels because the groups usually begins recruiting their member using unclear recruitment, initiation, and even some of the members are forced to be members of the group. The recruitment usually starts with the interaction among students because they often hang out in the same place with that group. And next, there will be an invitation by the group seniors and eventually they are forced to get involved in a student brawl. Besides, the juniors usually want to be recognized by group members; especially by seniors therefore they join their call. The pride for the juniors is when they are recognized as the members of the group, moreover when their seniors know them; they can be respected by the other group members because of this recognition.

Within these groups, they do not have any clear and structured recruitment, everything is flowing naturally. Everything begins from the interaction happening during the break time in the cafeterias around their schools. Out of three observed schools, only SMK N 1 Cibadak which has its own cafeteria. Therefore, for the other two schools, the students are free to go to the food stalls around the school. The interaction is among X graders with XI and XII graders. The inte- 
raction generally begins with the introduction, communication, or discussions about their mutual junior high schools, houses, hobbies, and mutual friends outside their school. This interaction intensively goes on as a regular basis during recess and after school.

Interaction and activity that they usually carry out together as a group lead them to experience the mutual emotional experiences shared within the group. Starting from going to school until getting back to home, they are always together and even hang out together. It makes them not having a lot of time at home or being alone unless they are sick or having family business. For them, being in adolescence stage at schools and having friend groups are everything.

The experience of one person is perceived by the others because they spend days together with the same activities as well. They only have little chance of not being together. Besides the positive experiences, they also have negative experiences such as doing student brawls. The sense of tension, high adrenaline, fear, and emotions are all mixed into one. There is a sense of satisfaction when they can escape from the brawls and cannot be touched by their opponents. That is why the students are addicted and challenged to repeat what they do. For the positive experience, they tend to help each other among within their group if anyone needs help.

Togetherness and friendship in the group are formed and tightened over a long time. There are several values that are shared in the group which are: (1) a high passion for groups and schools, so that they regard their group and school are better than the others (ethnocentrism), (2) loyalty over their group (solidarity), (3) feeling of unity, (4) protection toward their fellow group members no matter what happens, (5) being helpful when the members of the group need help, whether they request it or not, (6) always hiding the mistakes of their fellow group members, and (7) mutual trust.

The solidarity formed within the group can lead to a brawl with the other schools or groups. This circumstance can happen because they have excessively high loyalty toward their group. The groups can be initiated based on both school and place to hang out.

However, the way how they show their love to their school is sometime wrong. This is exactly what makes solidarity can lead to a negative attitude. The presence of solidarity does not always bring positive impacts. On one side, solidarity can be a positive impact. However, on the other, solidarity can be a negative influence as it preserves the old conflict among schools or groups that happen since long time. The solidarity within the group creates a feeling of equality, a sense of unity, friendship, trust, and mutual help. The solidarity also increases the existence of shared responsibility and even leads to interdependence with each other. This is exactly what leads the brawl between students keep on existing until today.

The solidarity of a group will greatly affect the student brawls because students have a high fidelity or loyalty to the group so that when there are conditions that require them to take action, they will voluntarily do the brawl. Or if there is an invitation from their fellow members of the group to take action, they will do it voluntarily as well. This solidarity will cause student brawls whenever the groups are under the threat from other groups or whenever there is an invitation from the group to do student brawls. The statements are supported by several informants' confessions who state that they will definitely do something when there is a threat or when the other schools or groups ridicule them. The students can fight when there is a call from the other members of their group. They explain that the invitation from a fellow member of the group is very hard to resist especially when it comes to the interest of their groups and schools.

Their love and solidarity toward their school is appreciated by the school itself. However, the way they show it is wrong because it can endanger their own lives, the lives of others, and disrupt public order. There are many factors which cause students brawls such as ridiculing the attributes that are used by other groups, stepping on school 
attributes used by another school, or keep the others' school emblem in the bottom. These are the example of some provocation, so that they will attack each other. They assume that the fight they do is a proof of their love to their school, evidence of selfdefense, and self-protection other schools attacks.

\section{DISCUSSION}

The brawls which occur in Sukabumi, especially the North region have been happening for long time involving students from different school groups and from different origins as well. The brawls that happened is one form of juvenile delinquency which is defined as fighting conducted by a group of students against another student groups of different schools that have had a rivalry. The brawls between students which often happen are among student groups of vocational high schools (SMK). The statement is reinforced by the explanation from Saleh (2004: 141) who states that a mass brawl between the schools are forms of violence which happen between two different students groups of schools which have hostility or competition. Therefore, student brawls begin with the hostility between SMKs. The long-standing enmity has been going on and passed from one generation to the next generation.

The dispute between student groups can appear in the form of an aggressive action or a reaction toward an action. When a student hurts and kills the other students, it is because that the student does not want to be injured or killed. Student brawl become a habit or routine that is committed by groups of vocational school students. There are many backgrounds which trigger a student brawl, but it all begins with the conflict between student groups. It starts with a conflict and then the solidarity of their group becomes the driving factor of the students to do brawl.

The existing conflicts keep on being maintained from one generation to the next generation. This action is done because they want to exist and to be recognized by the other group of students. Maftuh supports this statement (2008: 35 ) by explaining that some cases of conflict between students are caused by some factors including: economic inequality among students, unavailable fulfillment of basic needs or psychological needs, and frustration-aggression, and loss of a relative.

The brawl between students that happen mainly comes from three factors. The students who do brawls are students who are in the middle-lower economic conditions. Seeing from the vocational high schools that they are currently studying in, the money to pay the school is quite cheap. Most students who need guidance are the students who have issues, such as family issues. There are some cases that are resulted from the impact of divorce. There are also those who simply do the brawl because their parents are too busy to earn money so that the students are lack of affection and attention from their parents or family.

Therefore, the students are looking for ways of impingement upon their disappointment. They are frustrated with the situation they experience starting from their economic problems, family, and bad friendship. These circumstances lead to a mixed feeling and finally accumulated into a fight action or clash with other students. While doing this action, the students will do anything to be able to beat students from other groups because their satisfaction and disappointment of life will be channeled.

The explanation is reinforced by Setiadi \& Kolip (2011: 377) who state that some impacts resulted from social conflicts including: (1) the improvement of strong sense of group solidarity. Group solidarity will emerge when the conflict involves other parties that trigger antagonism (conflict) with their group, (2) the destruction of the unity of the group. When conflicts are not successfully resolved, the violence or war will happen. Then, the unity of the group will be destroyed, (3) A change in the individual's personality. In a group that is experiencing conflict, the person or group of people who previously used to have quiet or introvert personality will turn into an aggressive and irritable individual, (4) the destruction of values and social norms, (5) the loss of pro- 
perty (material ) and human casualties.

There are several theories that descri-

be how the brawl between students can occur. Based on Sarwono \& Meinarno (2009: 35), there are several theories of sources which cause a student brawl namely ethnocentrism theory, realistic conflict theory, and relative deprivation theory. In connection with the findings in the field, these theories explain how the fight can happen. However, the most dominant theory is ethnocentrism theory. The students always assume that their group and school are better, higher, and more dignified than any other group of high school students. When there are other school groups that they think disturb or even threat their school groups existence, they will do everything to eradicate that threat. With that feeling, the prejudice owned by students to other school groups will always exist.

The other theories which support the cause of brawl between students occur in Sukabumi are described by Maftuh (2008: 36-38) namely: social learning theory, social identity theory, reputation improvement theory, and irrational theory. These theories can be used to explain the source of student brawls which happen in Sukabumi. The student groups consist of students from different classes and levels who are commonly referred to as junior and senior students. Many examples can be taken from the findings of researcher which show that the junior students are invited by an older or senior students first do the fight. In addition, it is shown by the findings of others that there is contagious fighting trend from one region to another.

The student group is established informally. The formation of student groups which are doing students brawl are without a clear recruitment and conditions. The formation can be based on the similarity of the school, region of residence, and similar interests. These groups are formed naturally as a result of the interaction process from the students; surrounding in order to meet their needs.

The need of the students to join the group is very high. By joining the student groups, students can survive their daily needs based on the adolescent development. Some of these needs are the need to blend with the surrounding environment, the need to be recognized in the group, the need for self-actualization, and so forth. In addition, many benefits are obtained when the students become the group members. By joining a group, students can feel comfortable and protected. Thus it makes the students to have a great desire to be incorporated into a group.

There are several benefits when individuals join the group, as described by Burn (Sarwono \& Meinarno, 2009: 169):

a. The group meets the individual needs to be meaningful and part of something. The existence of the group makes people do not feel alone. They also can feel the feeling of being loved and protected.

b. Group is a source of identity. Individuals who become members of the group can define themselves; they recognize themselves as members of a group and behave in a manner of that group.

c. Group is as a source of information about the world and about them. The presence of other people in this group can give us information about many things including about who we are.

The above benefits are perceived by the students so that they persist in being the members of a group notwithstanding their violent actions against the values and norms such as doing the brawls. There are many factors which cause the students to join a group; both internal and external factors. Therefore, there is an internal driving factor of the students in joining a group and also external factors of their friendship group.

Vaughan and Hogg (Sarwono \& Meinarno, 2009: 170) support this statement by explaining that some reasons for students to become a member of a group are: proximity, mutual interests, attitudes, and beliefs, interdependence to achieve a certain goal, positive feedback support, and emotional support. The group can also provide emotional support and social identity for its members. Individual membership in a group makes an 
individual possess an identity. The members know who they are because they become a member of a group.

The biggest reason when the students want to join a group is to fulfill the needs of its development as a teenager that they cannot be achieved elsewhere. As described by Sunarto \& Hartono (2008: 68), the needs of adolescents are divided into several sections:

a. Organic needs, including eating, drinking, breathing, and sex;

b. Emotional needs, including the need to gain sympathy and recognition from other parties known to n'Aff;

c. achievement needs, including the development of their potential and psycho-physical ability;

d. needs to defend themselves and to develop their types.

Solidarity or social solidarity is a concept that refers to the state of friendliness and based on the common interests among its members. In line with the explanation Durkheim (Johnson, 1986: 181), solidarity refers to a state of the relationship between individuals and groups based on moral feelings and beliefs held together and reinforced by their shared emotional experience. It can be seen that by achieving the confidence and experience in the group, the members will create a feeling of kinship solidarity and the bond among students will be closer because of their mutual interests.

This explanation is supported by Johnson (1986 pp: 262) who explains that the unity of social solidarity, friendship, and mutual trust are arising from the shared responsibility and interests among its members. The tangible manifestation of the joint relationship will bear the emotional experience, thereby strengthening the relationship between students. Therefore, it can be concluded that the solidarity owned by the student group is very high. If the students trust each other, they will be united as one and formed lasting friendships so that whatever their friends do, they can justify it. In addition, the students will share mutual respect, be encouraged to be responsible, and pay attention to the interests of other group members.

The student groups experience the growth and development through several phases, namely: performing phase (phase of achievement), norm establishment phase, storming phase (phase of transition), and forming phase (phase of clustering). Each student in the group performs various approaches and assessments over the other students and tries particular acts to get a reaction from other members. Each student displays different behaviors. Gradually, the students begin creating patterns of relationships among group members which is considered as a basic pattern of group behavior.

High solidarity within the group causes the students dare to take actions which violate the norms such as conducting student brawl. Besides, the group does not have integration with the other group. The social control among groups does not exist as well. In fact, the students help each other and encourage the violent actions during the brawl.

Solidarity formed in the group will lead to a fight for any potential threat which comes from the other groups. This solidarity will also cause a student brawl as long as they are still in conflict with the other groups and maintain that conflict.

Solidarity within a group does not create integration among groups and lead to the lack of social control among the group members. This lack of control is related to the social adjustments carried out by the students to the surrounding environment. Willis (2010, p. 92) distinguishes the adjustments that are owned by adolescent students into three parts: (1) Self Adjustment in the Family, (2) Self adjustment in school, (3) Self Adjustment in Society.

Based on the above explanation, it can be concluded that adolescence is a problematic period of age because there are many problems associated with adolescent including some issues with themselves, peers, parents, and the community. The mentioned adjustments have been causing some problem to the students and they can perform deviating action when they are not able to adapt to the surrounding environment.

From some brawls which happened, it 
can be identified that there are some aspects of juvenile delinquency trend as described by Mariah (2007) namely (1) the behavior that violates the rules or status, (2) the behavior which endanger themselves and others, (3) the behavior which causes material casualties, and(4) the behavior that cause in physical casualties. The four behaviors show that the brawl is not only a normal juvenile delinquency and cannot be tolerated. Santrock (2003: 21) states that conformity is created when people imitate the attitude or behavior of another person due to the real pressure or imaginary pressure that the create themselves.

The solidarity within a group will greatly affect the student brawls because students have a high fidelity to the group so that when there are conditions which require them to take action, they will voluntarily do the brawl. In addition, when there is a call from their fellow group members to do the brawl, they will also carry out such action voluntarily. Solidarity will cause the student brawls when their group is under the threat from the other groups or when their fellow group members ask them to do it.

This solidarity makes them believe that what they are doing is right. Besides, there are number of factors which push them to think that fighting is right. In addition to it, the students usually have uncontrolled emotion. By the time the brawl is happening, this emotion will continue to flare up and rise so that their desire to attack and even to kill becomes their satisfaction.

\section{CONCLUSION}

First, the brawl between students has become a habit for student groups who have a history of hostility in Sukabumi. In general, the cause of brawl between students in Sukabumi is due to the presence of conflicts or resentments among different groups of schools that continue to be inherited. The other causes are the students who go into vocational high schools usually have economic and family problems, wrong sense of solidarity in their groups, the problem of public transportations which are unwilling to take student group so that the students get together in groups in certain pint or their base camp or place to hang out, the school which does not fully carry out the teaching and learning process, lack of discipline in schools, lack of application of noble character, inadequate equipment, facilities, and infrastructure, problems of geographical location between the school and home, alumni and peer influence, spontaneity or conditional action, the use of schools by student attributes of another school or outside of school, students defense from other groups attack, and low self-concept.

Second, the process of a student to join a group happens naturally and based on the location of their houses because of proximity or residence, the same interests, and their place of hang out. In addition, the participation of students become members of the group begins with the coercive solicitation of group members from seniors to juniors. Therefore, the junior students are hard to refuse the invitation to join the group. The recruitment is done randomly by seniors depending on the interaction that they have with the juniors.

Third, the process of solidarity establishment within a group continues to grow in line with the growth of the group itself. The process of formation begins with the interaction that involves the group members. Then they carry out activities together. And finally they build an engagement of emotional feelings which exists among group members. The existing solidarity causes the emergence of a sense of equality, unity, friendship, trust, mutual accountability, mutual help, and mutual interdependence among group members.

Fourth, solidarity which is formed within the group can lead to the brawl between students, especially when there is a threat from another group against their group. The brawl also happens when there is a conflict involving their groups and students group of different schools. Conflicts between different groups of schools will always exist because the conflict is maintained by the group from one generation to generation. Solidarity within the group with the ethnocentrism of school alma mater will force the students 
to do everything, even actions which trespass the norms. When the students are in a group, individual personalities merge into a collective personality of that group.

\section{REFERENCES}

Johnson, D. P. 1986. Teori Sosiologi Klasik dan Modern 1. Jakarta : Gramedia Pustaka.

Maftuh, B. 2008. Pendidikan Resolusi Konflik : Membangun Generasi Muda yang Mampu Menyelesaikan Konflik Secara Damai. Bandung: Sekolah Pasca Sarjana UPI.

Mariah, U. 2007. Peran Persepsi Keharmonisan Keluarga Dan Konsep Diri Terhadap Kecenderungan Kenakalan Remaja. Tesis. Fakultas Psikologi, Universiatas Gajah Mada, Yogya-
karta.Saleh, A. I. 2004. Tawuran Pelajar Fakta Sosial yang Tak Berkesudahan di Jakarta. Yogyakarta: IRCISOD.

Saleh, A. I. 2004. Tawuran Pelajar Fakta Sosial yang Tak Berkesudahan di Jakarta. Yogyakarta: IRCISOD.

Santrock, J.W. 2003. Adolescence: Perkembangan Remaja. Jakarta: Erlangga.

Sarwono, W. S. dan Meinarno, A. E. 2009. Psikologi Sosial. Jakarta: Salemba Humanika.

Setiadi, M. E. \& Usman K. 2011. Pengantar Sosiologi. Jakarta: Kencana.

Sunarto dan Hartono, A. 2008. Perkembangan Peserta Didik. Jakarta : Rineka Cipta.

UU RI No. 20 Tahun 2003 tentang Sistem Pendidikan Nasional. Jakarta: depdikbud.

Willis, S. S. 2010. Remaja dan Masalahnya. Bandung: Alfabeta. 